\title{
The Use of Valuing Strategies into Enhancing Creativity in EFL Writing
}

\author{
Luqman Rababah \\ Correspondence: LuqmanRababah, School of Arts and Languages, Jadara University, \\ Irbid, Jordan. P. O. BOX 733, Postal Code 20110, Jordan. \\ E-mail: Rababah80@gmail.com
}

Ala'Eddin Abdullah Ahmed Banikalef

School of English Language and Literature, Faculty of Arts and languages, Jadara

E-mail: alaeddin@jadara.edu.jo

Received: February 19, 2019

Accepted: March 12, 2019 Published: March 15, 2019

doi:10.5296/elr.v5i1.14507

URL: https://doi.org/10.5296/elr.v5i1.14507

\begin{abstract}
The present study aimed at finding out the valuing strategies used by EFL teachers to enhance student's creativity in writing. The present study made use of a qualitative approach to obtain data from the Discovery School students in Amman, Jordan and to determine the answers to the research questions. This study was carried out in the one hundred branches of Discovery Schools (DSs) located in Amman, Jordan for the Academic year 2018/2019. Using a convenience sample, ten EFL teachers were chosen as a sampling for the current study. The present study conducted interviews with EFL teachers and observed them. The participants were selected from the first secondary cycle as the cycle holds significance. To check the trustworthiness and credibility of qualitative data, the researcher utilized two strategies, triangulation and member check. The interview data analysis showed that eight teachers believed that using the strategy was important. On a negative note, the results from the observation showed that only three teachers actually employed this strategy among their teaching techniques. Further research is recommended on the same topic in different settings.
\end{abstract}

Keywords: Valuing, Encouragement, Behaviorism, Writing, Creativity

\section{Introduction}

Valuing students' work has critical roles in enhancing their creativity in general and their writing in particular. The assumption is that creativity can be learned and can be supported 
via stimulus, reinforcement and response (Craft, 2003). Creativity is a reaction of an individual towards environmental influences. In this regard, a reinforcer is something reinforcing a desired response and can be in the form of a verbal phrase, a good grade, a feeling of increased accomplishment or rewards (Krashen, 1982; Al-Jarf, 2007).

The students' inability to write creatively and their instructors' devaluation of their work could discourage them. In an EFL classroom, the majority of students and instructors perceive writing to be a chore where students steer clear of writing activities owing to their fear of making mistakes and their inability to produce ideas. Al-Jarf (2007) contended that writing creativity neither needs a special talent nor a high degree of proficiency in EFL.Thus, this justifies the use of interviews and observations to find out the valuing strategies used by teachers and to answer the research question entitled, "What is the actual use of valuing teaching strategies used by EFL teacher in enhancing their students' work?"

\section{Literature Review}

\subsection{The Behaviorist Theory}

This theory focuses on the behaviour of the individual as opposed to his mind, and the theory explains selection and intention. Behaviour refers to observable activities and does not consider mental processes, which may stem from observed behaviour. Learning occurs when the organism involves itself in interaction with the environment. Such experience facilitates the modification or changing of the behaviour.

Using this viewpoint, researchers have noted various learners' behaviours in terms of their reactions to specific stimuli in controlled conditions. The learner was deemed to be receiving stimuli passively from external forces, and, eventually, he learned. The fundamental learning processes were considered to be constant throughout different species, and the species under study did not make any significant difference. In other words, learning laws are similar whether the species are dogs, rats, pigeons, monkeys or humans (Bandura, 1986). In this context, a poet composing a poem was deemed to be controlled by prior stimuli during the act much like a chicken laying eggs (Skinner, 1972).

Skinner's theory is based on the premise that learning is a function of overt behaviour and changes stem from the response of the individual to a stimulus occurring in the environment (Skinner, 2011). A response generates an outcome like defining a word, hitting a ball or solving a problem in math. In case a specific stimuli-response (s-r) pattern is supported (rewarded), the individual naturally responds. Support or reinforcement is the core factor in Skinner's S-R Theory. A reinforcer is something that supports and contributes to the strength of the expected response and could be in the form of a verbal praise, a good grade, or a feeling of accomplishment/satisfaction. Moreover, behaviourism posits that all human behaviour should be objectively examined the way in which rats and monkeys are examined, and studies would lead to controlled as well as predictable behaviour. Skinner added that current behaviour could be explained by prior history, current circumstances and the inherited genetic makeup (Bandura, 1986).

Another theory comes from Bandura (1986). His Social Learning Theory stresses the importance of observing and modelling behaviours, attitudes and emotional response of others. According to Bandura (1986), learning would be overtly laborious and hazardous if 
people only depended on their own actions effects for their consequent actions. However, most human behaviour is learned through observations via modelling-in other words, through the observation of others. He said that -individuals develop ideas of the performance of new behaviours and later, this coded information assists in carrying out other related actions ( $p$. 22). Social learning provides an insight into human behaviour with regard to ongoing reciprocal interaction between influences of cognitive, behavioural and environmental nature. From the behaviourist perspective, creativity may be maximized via rewards and motivation by using several approaches (i.e., praise, good grade, or feelings of increased accomplishment/ satisfaction) that reinforce the desired reaction.

\subsection{Empirical Studies}

Several studies have been done on methods used to value students' work (Farmer, Tierney, \& Kung-Mcintyre, 2003; Madjar \& Oldham, 2002; Selart, Nordström, Kuvaas, \& Takemura, 2008). Selart et al. (2008) studied the effects of types of rewards on self-regulation, intrinsic motivation and creativity. Forty-two undergraduate students were randomly assigned into three groups, namely, performance-contingent reward group, an engagement-contingent reward group and a control group. Participants in the engagement-contingent reward group and the control group achieved higher rated creativity than participants in the performance-contingent reward group. Farmer et al. (2003) found that an individual's creativity was highest when he perceived himself as a creative person and perceived himself as valuing creative work. Creativity can even be fostered by the behavior of so-called -important others. Madjar and Oldham (2002) found that the creative performance of a person was significantly related to support for creativity from both teachers and families sources.

\section{Methods}

The present study made use of a qualitative approach to obtain data from the Discovery School students in Amman, Jordan and to determine the answers to the research questions. The qualitative approach is useful to help the researcher to explore social or human problems and then build a complex picture, analyze words, report detailed information and conduct the study in a natural setting (Creswell, 2012; Denscombe, 2010). The importance of using a qualitative method for this study is to ensure richness of detail. The present study was carried out in the one hundred branches of Discovery Schools (DSs) located in Amman, Jordan for the Academic year 2018/2019. Ten EFL teachers were chosen as a sampling for the current study.

The present study conducted interviews with EFL teachers and observed them. The participants were selected from the first secondary cycle as the cycle holds significance; students were instructed and taught the English language within e-content since age 6 and by the secondary cycle they are expected to be capable of developing three well-defined paragraphs (Ibnian, 2010). Convenience sampling was utilized in the research in case the researcher is desirous of obtaining a reasonable approximation of the truth and it provides useful information particularly in a pilot study (Creswell, 2012). This study employed two data collection instruments, namely,semi-structuredinterviews and observations. To check the trustworthiness and credibility of qualitative data, the researcher utilized two strategies, triangulation and member check. 
3.1 Data Collection and Analysis

All EFL teachers who participated in the present study were interviewed to answer the research questions regarding valuing their students' work. Moreover, observations were initiated after the interviews. The researchers use collected, analyzed and interpreted qualitative data. They have made use of preparing and organizing data, exploring and coding database, describing findings and forming themes, representing and reporting findings and interpreting the findings. The responses of the interviewed and observed participants were coded.

\section{Results}

\subsection{Interview Results}

Valuing students' writings was the theme that arose from the feedback provided by the teachers. The teachers stressed respecting and valuing students' written work as they were convinced that following such a strategy was among the most important steps that a teacher should adopt. The interview data analysis showed that eight teachers believed that using the strategy was important. Specifically, TD explained his experience in valuing students' writing. He stated that I treat every student writing as an important draft to provide the students with the feeling of a sense of accomplishment ... when one of my students write a perfect essay, I print the said essay and display it in the school's bulletin board or provide and praise the student by presenting it to him in front of the class. (TD, Interview, November 18, 2018). Similarly, TH stated that students should be valued by respecting what they wrote and said. For instance, a good-written work deserves praise in front of the class. He claimed to employ the same strategy by stating that "My way of valuing students' works is by respecting what they wrote, said and accomplished. Upon coming across a good essay while checking students' works, I try to make it a point to praise the student in front of his peers to respect his work" (TH, Interview, November 11, 2018). TF, on the other hand, did not make it a practice to value students' work as explained by the above teachers but only confined himself to personally checking students' writings (TF, Interview, November 13, 2018). As evident from the teachers' feedback, their opinions concerning valuing student work varied. Every teacher had his own method to value work accomplished by students. Some evinced their respect for students' work by displaying them on the school's bulletin board. In addition, some teachers who informed students of their rewards when they wrote well and advised of the penalties when they wrote badly received better written essays compared to those who did not make such demands.

\subsection{Observation Results}

Despite the contention of the majority of the participating teachers expressed in their interview sessions that they valued their students writing, the results from the observation showed that only three teachers actually employed this strategy among their teaching techniques. TD was observed valuing his students' writings in various ways. For instance, when one of his students wrote a perfect essay, he printed his writing and made it into a gift certificate to present to the student. This made the student feel that his work was valued and worthy, and he felt that he had accomplished something worthwhile. One of his students even 
cried from happiness when TD handed him the finished work (TD, Observation 3, December 25, 2018).

Valuing students' writings strategy was also observed from TG who printed a perfect work and posted it on bulletin boards in the classroom and the school (TG, Observation 3, December 26, 2018) and from TA who presented the students with appreciation certifications for their accomplishments. The students were happy, as they felt their teacher valued their work (TA, Observation 3, December 20, 2018).However, the results from the observations regarding the employment of this strategy were different from the responses obtained from teachers in the interview sessions. The results showed that only three out of eight teachers, who claimed to use the strategy in their interviews, actually employed valuing their students writing in their teaching methods.

\section{Discussion}

Valuing students' writings was the theme that arose from the responses provided by teachers. The teachers stressed respecting and valuing students ${ }^{6}$ written work, as they are convinced that following such a strategy is among the most important steps that a teacher should adopt. According to the behaviourist tradition, creativity is a reaction of an individual towards environmental influences. This viewpoint assumes that creativity is learned and can be supported via stimulus, reinforcement and response (Craft, 2001). In this regard, a reinforcer is - something that reinforces the correct response and can be in the form of a verbal phrase, a good grade, a feeling of increased accomplishment or satisfaction (Krashen, 1982).

On the basis of the affective-filter hypothesis, a second language learner's emotions function as adjustable filters permitting or preventing acquisition input criteria. Krashen (1994) stated that highly motivated people who are self-confident, have good self-image and are low anxiety learners have more potential to succeed in learning a second language. Valuing students' work has a critical role in enhancing their creativity in general and in writing in particular (Fasko, 2001). Fasko (2001) explained, - When students understand that their teachers value' creativity, then this message has a positive effect on creativity.

\subsection{Conclusion and Recommendations}

The present study employed a distinct and practical look at how creativity can be promoted in the classroom to enhance EFL writing. Carrying out the study in a natural environment may pose some challenges because of the presence of uncontrollable extraneous factors and unpredictable situations in the collection of data and this may compromise the study's reliability and validity. Along the same line of contention, creating a social rapport with students encourages them to write and contribute to the classroom activities. In order to build this relationship, the students' backgrounds have to be respected, and their every need and challenge in writing should be considered and tackled through efficient use of writing activities. Further research is recommended on valuing strategies in different settings.

\section{References}

Al-Jarf, R. (2007). Online instruction and creative writing by Saudi EFL freshman students, King Saud University, Saudi Arabia. Asian EFL Journal, 22(1), 92-107.

Almwajeh, M. O., \& Rababah, L. (2018). Literature is the best tool of awaking moral understanding and evaluation: Wendell Berry's the Long-Legged House. Journal for 
Translation \& Literary Studies, 2(2), 69-80. https://doi.org/10.24093/awejtls/vol2no2.5

ALRababah, I., \& Rababah, L. (2019). The Use of Brainstorming Strategy Among Teachers of Arabic for Speakers of Other Languages (ASOL) in Writing Classes. International Journal of English Linguistics, 9(1), 15-24. https://doi.org/10.5539/ijel.v9n1p15

BaniKhlaf, A., \& Rababah, L. (2018). Gender differences and emotional expressiveness on Facebook: An analysis of prosodic features among Jordanian facebookers. Studies in Linguistics and Literature, 2(3), 180-194. https://doi.org/10.22158/s1l.v2n3p180

Banikalef, A., Marlyna, M., \& Ashinida, A. (2014). Linguistic Analysis of Humor in Jordanian Arabic among Young Jordanians Facebookers. AWEJ, (3), 304-318.

Banikalef, A. \& Bataineh, K. B. (2017). A Sociolinguistic Study of Speech Act Realization Patterns in Jordanians' Facebook Status Updates. International Journal of Linguistics, 9(3), 185-204. https://doi.org/10.5296/ijl.v9i3.11245

Craft, A. (1999). Creative development in the early years: Some implications of policy for practice. The curriculum Journal, 10(1), 135-150. https://doi.org/10.1080/0958517990100110 Craft, A. (2003). Creativity across the primary curriculum. London: Routledge. https://doi.org/10.4324/9780203457283

Creswell, J. (2012). Educational research: Planning, conducting, and evaluating quantitative and qualitative research (4th ed.). Thousand Oaks, CA: Sage Publications.

Denscombe, M. (2010). The good research guide: For small scale research projects (4th ed.). Maidenhead: McGraw-Hill Open University Press.

Farmer, S. M., Tierney, P., \& Kung-Mcintyre, K. (2003). Employee creativity in Taiwan: An application of role identity theory. Academy of Management Journal, 46(5), 618-630. https://doi.org/10.2307/30040653

Ibnian, S. (2010). The effect of using the story- mapping technique on developing tenth grade students' short story writing skills in EFL. English Language Teaching, 3(4), 181-194.

Jdaitawi, T., Ishak, N., Taamneh, A., Gharaibeh, N., \&Rababah, M. (2011). The effectiveness of emotional intelligence training program on social and academic adjustment among first year University students. International Journal of Business and Social Science, 2(24).

Krashen, S. (1982). Writing: Research, theory, and application. Oxford: Pergamon.

Madjar, N., Oldham, G. R., \& Pratt, M. G. (2002). There's no place like home? The contributions of work and nonwork creativity support to employees' creative performance. Academy of Management Journal, 45(4), 757-767. https://doi.org/10.5465/3069309

Rababah, I., \& Rababah, L. (2017). Investigating Arabic to Speakers of Other Languages (ASOL) Lecturers' Attitudes towards Utilizing Flipped Classroom Instruction (FCI): A Qualitative Study at Jordanian Public Universities. International Education Studies, 10(7), 94-104. https://doi.org/10.5539/ies.v10n7p94

Rababah, L. (2018). An adapted version of Torrance test of creative thinking (ttct) in efl/esl writing: a rubric scoring and a review of studies. International Journal of English and Education, 7(2), 128-136.

Rababah, L. M., Mohamed, A. H. Bin, Jdaitawi, M. T., \& Melhem, N. Z. B. (2013). The level of creativity in English writing among Jordanian secondary school students. Arts and Design 


\section{Macrothink}

Studies, 10, 25-29.

Rababah, L., \& Almwajeh, M. (2018). Promoting creativity in EFL/ESL writing through scaffolding strategy. International Journal of English and Education, 7(3), 148-160.

Rababah, L., \& Melhem, N. (2015). Investigation into Strategies of Creativity in EFL Writing in Jordan. Journal of Literature, Languages and Linguistics, 3(5), 14-25.

Rababah, L., Alshehab, M., \& Melhem, N. Z. B. (2018). Exploring the Factors that Hinder Jordanian Students in Developing Creativity in EFL Writing. International Journal of English and Education, 7(3), 161-170. https://doi.org/10.17758/EIRAI.F0117427

Rababah, L., Bani-Melhem, N., Jdaitawi, M., Rababah, B., \& Rababah, O. (2012). EFL teachers' barriers to the use of ICT in instruction in Jordan. In Proceedings of the 1st International Conference on Behavioural and Social Science Research (ICBSSR) (pp. 1-5).

Selart, M., Nordström, T., Kuvaas, B., \& Takemura, K. (2008). Effects of reward on self-regulation, intrinsic motivation and creativity. Scandinavian Journal of Educational Research, 52(5), 439-458. https://doi.org/10.1080/00313830802346314

Skinner, B. F. (1972). Beyond freedom and dignity. New York: Bantam Books.

Skinner, B. F. (2011). About behaviorism. NY: Vintage.

\section{Copyright Disclaimer}

Copyright reserved by the author(s).

This article is an open-access article distributed under the terms and conditions of the Creative Commons Attribution license (http://creativecommons.org/licenses/by/3.0/). 